\title{
Bioactive properties of the medicinal mushroom Leucopaxillus giganteus mycelium obtained in the presence of different nitrogen sources
}

\author{
Lillian Barros, Paula Baptista, Letícia M. Estevinho, Isabel C.F.R. Ferreira * \\ CIMO-Escola Superior Agrária, Instituto Politécnico de Bragança, Campus de Sta. Apolónia, Apartado 1172, 5301-855 Bragança, Portugal
}

Received 11 January 2007; received in revised form 16 February 2007; accepted 28 March 2007

\begin{abstract}
Leucopaxillus mushroom species are used in the chemical industry for extraction of clitocybin antibiotic and particularly the edible mushroom Leucopaxillus giganteus can be found in Northeast Portugal. Nevertheless, the production of its mycelium for pharmacological applications has not been explored. Herein, the mycelium obtained in the presence of four different nitrogen sources was investigated with regard to phenol production and antimicrobial and antioxidant properties. Phenol concentration increased along the growth time as a response to the oxidative stress and therefore free radical production. Although significant differences for mycelium growth between the nitrogen sources had not been observed, $\left(\mathrm{NH}_{4}\right)_{2} \mathrm{HPO}_{4}$ proved to be the most appropriate to increase bioactive properties, leading to the highest phenol content and lowest $\mathrm{EC}_{50}$ and $\mathrm{MIC}$ values. The antimicrobial capacity was screened against Gram positive and Gram negative bacteria, and fungi. The samples selectively inhibited the growth of Gram positive bacteria, Staphylococcus aureus being the most susceptible one. Gram negative bacteria and fungi were resistant to the extracts. Antioxidant activity was calculated by the reducing power assay, the scavenging effect on DPPH radicals, and hemolysis and lipid peroxidation inhibition. Significantly negative linear regressions were established between phenols/flavonoids contents, which increased along the mycelia growth time and antioxidant activity.
\end{abstract}

(c) 2007 Elsevier Ltd. All rights reserved.

Keywords: Mushroom mycelium; Nitrogen source; Antimicrobial activity; Antioxidant potential; Nutraceuticals

\section{Introduction}

Mushrooms have become attractive as a functional food and as a source for the development of drugs and nutraceuticals (Barros et al., in press; Barros, Ferreira, Queirós, Ferreira, \& Baptista, 2007; Ferreira, Baptista, Vilas-Boas, \& Barros, 2007; Cheung \& Cheung, 2005; Mau, Chang, Huang, \& Chen, 2004; Yanga, Linb, \& Maub, 2002). In addition to dried mushrooms, alternative or substitute mushroom products are mycelia which could also be used as food and food-flavouring material, or in the formulation of nutraceuticals and functional foods. The add-value aris-

\footnotetext{
* Corresponding author. Tel.: +351 273303219; fax: +351 273325405.

E-mail address: iferreira@ipb.pt (I.C.F.R. Ferreira).
}

ing from mushrooms/mycelia is bioactive properties can lead to an increase in its consumption and therefore stimulate the commercialisation of local edible species and the in vitro production of mycelium mushroom (e.g. for the pharmaceutical industry). Over two-thirds of cancerrelated deaths could be prevented through lifestyle modification, particularly through dietary means, and mushrooms consumption could contribute to minimize cancer risks through antioxidant input (Borchers, Keen, \& Gershwin, 2004).

Leucopaxillus species have received extensive attention for medical application, and are being used in chemical industry for extraction of clitocybin antibiotic (Breitenbach \& Kränzlin, 1991). Leucopaxillus giganteus (Sowerby) Singer is a common Portuguese edible mushroom and 
belongs to the phyla Basidiomycete, order Agaricales, and family Tricholomataceae. However, it is difficult and time consuming to cultivate the fruiting bodies of L. giganteus to obtain bioactive compounds. At present, between $80 \%$ and $85 \%$ of all medicinal mushroom products are derived from the fruiting bodies, which have been either commercially farmed or collected from the wild. Only 15\% of all products are based on extracts from mycelia (Lindequist, Niedermeyer, \& Jülich, 2005). In spite of a great need for useful bioactive metabolite production by submerged cultivation of mushrooms, the bioprocess development is still far from being thoroughly studied (Cho et al., 2002; Wasser, Elisashvili, \& Tan, 2003; Zhong \& Tang, 2004). Usually, culture medium is important for the yield of cultivation products and the nitrogen source generally plays a significant role, as it is essential for cell proliferation and metabolite biosynthesis. In submerged cultivation of mushroom Tremella mesenterica, Wasser et al. (2003) demonstrated that the type and concentration of the nitrogen source strongly influenced cell growth and polysaccharide production. Despite other studies carried out on the effect of the nitrogen source on the growth of edible mushrooms, particularly on Nigerian species Vovariella speciosa (Fr. Ex. Fr.) Sing. (Fasidi \& Akwakwa, 1996), Psathyerella atroumbonata (Pegler) (Jonathan \& Fasidi, 2001), Lentinus subnudus (Berk.) (Gbolagade, Fasidi, Ajayi, \& Sobowale, 2006), Chinese species Pleurotus tuber-regium (Fr.) (Wu, Cheung, Wong, \& Huang, 2003; Wu, Cheung, Wong, \& Huang, 2004), Cordyceps militaris (Mao \& Zhong, 2006) and Brazilian specie Agaricus brasiliensis (A. blazei) (Fan, Soccol, Pandey, \& Soccol, 2007), no studies were found for the Portuguese species and no reports are known about the influence of the nitrogen source in the bioactive properties of wild edible mushrooms. In this work, we evaluated the effects of various nitrogen sources on the production and functional properties of Leucopaxillus giganteus mycelium. The mycelium growth was followed over time $(15,30$, 45 and 60 days) and the antimicrobial activity was screened against different microorganisms, namely Gram positive (Bacillus cereus, B. subtilis, Staphylococcus aureus) and Gram negative (Pseudomonas aeruginosa, Escherichia coli, Klebsiella penumoniae) bacteria and fungi (Candida albicans, Cryptococcus neoformans), provided by collection strains or clinical isolates. The antioxidant activity was evaluated for each nitrogen source and for each growth day, using several assays: free radical scavenging capacity, reducing power, oxidative erytrocytes hemolysis inhibition and lipid peroxidation inhibition. All these antioxidant activity parameters were correlated to the phenolic and flavonoidic content present in the samples.

\section{Materials and methods}

\subsection{Biological material}

Mycelia of L. giganteus (Sowerby) Singer was isolated from sporocarps collected under grassland in Bragança (northeast of Portugal) (Herbarium of Agrarian School Instituto Politécnico Bragança) on solid Melin-Norkans $(\mathrm{MMN})$ medium $\mathrm{pH} 6.6\left(\mathrm{NaCl} 0.025 \mathrm{~g} / \mathrm{L} ;\left(\mathrm{NH}_{4}\right)_{2} \mathrm{HPO}_{4}\right.$ $0.25 \mathrm{~g} / \mathrm{L} ; \quad \mathrm{KH}_{2} \mathrm{PO}_{4} \quad 0.50 \mathrm{~g} / \mathrm{L} ; \quad \mathrm{FeCl}_{3} \quad 0.050 \mathrm{~g} / \mathrm{L} ; \quad \mathrm{CaCl}_{2}$ $0.50 \mathrm{~g} / \mathrm{L} ; \quad \mathrm{MgSO}_{4} \cdot 7 \mathrm{H}_{2} \mathrm{O} \quad 0.15 \mathrm{~g} / \mathrm{L} ;$ thiamine $0.10 \mathrm{~g} / \mathrm{L}$; casamino acids $1.0 \mathrm{~g} / \mathrm{L}$; malt extract $10 \mathrm{~g} / \mathrm{L}$; glucose $10 \mathrm{~g} /$ $\mathrm{L}$; agar $20 \mathrm{~g} / \mathrm{L}$ ), following the method of Brundrett, Bougher, Dell, Grove, and Malajczuk (1996). The strain was maintained in the same medium at $25{ }^{\circ} \mathrm{C}$ in the dark and sub-cultured every month.

\subsection{Effect of nitrogen source on the mycelia growth rate}

For aseptic establishment of the assay, 10 hyphal plugs (5 mm diameter) of 1-week-old L. giganteus mycelia were transferred into flasks $(700 \mathrm{ml})$ containing $250 \mathrm{ml}$ of MMN liquid medium performed with four different nitrogen sources: potassium nitrate, ammonium nitrate, ammonium hydrogenophosphate and sodium nitrite. Inoculated flasks were shacked and maintained in the dark at $25^{\circ} \mathrm{C}$. After $15,30,45$ and 60 days of growth the mycelium was recovered from the liquid medium by filtration, washed with distilled water, weighted (fw) and dried at $50{ }^{\circ} \mathrm{C}$, over $24 \mathrm{~h}$, to obtain the yield of biomass ( $\mathrm{dw})$. Three replicate flasks of each combination were performed (12 flasks per nitrogen source).

\subsection{Samples preparation for antimicrobial and antioxidant activities assays}

The dried mycelium $(\sim 1 \mathrm{~g})$ obtained after different growth times $(15,30,45$ and 60 days) and in the presence of each nitrogen source (potassium nitrate, ammonium nitrate, ammonium hydrogenophosphate and sodium nitrite) was extracted by stirring with $100 \mathrm{ml}$ of methanol at $25^{\circ} \mathrm{C}$ at $150 \mathrm{rpm}$ for $24 \mathrm{~h}$ and filtered through Whatman No. 4 paper. The residue was then extracted with one additional $100 \mathrm{ml}$ portion of methanol, as described earlier. The combined methanolic extracts were evaporated at $40{ }^{\circ} \mathrm{C}$ to dryness and redissolved in methanol for antioxidant activity assays or in DMSO for antimicrobial activity assays, at a concentration of $10 \mathrm{mg} / \mathrm{ml}$, and stored at $4{ }^{\circ} \mathrm{C}$ for further use.

\subsection{Antimicrobial activity}

\subsubsection{Standards and reagents}

Ampicillin and cycloheximide were of the highest available quality, and were purchased from Merck (Darmstadt, Germany). Water was treated in a Mili-Q water purification system (TGI Pure Water Systems, USA).

\subsubsection{Microorganisms and culture conditions}

Microorganisms CECT were obtained from the Spanish type culture collection (CECT) of Valencia University, while microorganisms ESA were isolated in the Northeast Hospital Centre (Bragança) from different biological fluids, and deposited in the Microbiology Laboratory of Escola 
Superior Agrária de Bragança. Gram positive (Bacillus cereus CECT 148, B. subtilis CECT 498, Staphylococus aureus ESA 7 isolated from pus) and Gram negative (Escherichia coli CECT 101, Pseudomonas aeruginosa CECT 108, Klebsiella pneumoniae ESA 8, isolated from urine) bacteria and fungi (Candida albicans CECT 1394, Cryptococcus neoformans ESA 3 isolated from vaginal fluid) were used to screen mycelia antimicrobial activity. Microorganisms were cultured aerobically at $37^{\circ} \mathrm{C}$ (Scientific 222 oven model, 2003 ) in nutrient agar medium for bacteria, and at $30^{\circ} \mathrm{C}$ (Scientific 222 oven model, 2003) in sabouraud dextrose agar medium for fungi.

\subsubsection{Test assays for antimicrobial activity}

A screening of antibacterial activities against the Gram negative and Gram positive bacteria and fungi was performed, and the minimal inhibitory concentration (MIC) was determined by an adaptation of the agar streak dilution method based on radial diffusion (Ferreira, Calhelha, Estevinho, \& Queiroz, 2004; Hawkey \& Lewis, 1994). Suspensions of the microorganism were prepared to contain approximately $10^{8} \mathrm{cfu} / \mathrm{ml}$, and the plates containing agar medium were inoculated $(100 \mu \mathrm{L})$. A $50 \mu \mathrm{L}$ volume of each sample was placed in a hole (depth $3 \mathrm{~mm}$, diameter $4 \mathrm{~mm}$ ) made in the centre of the agar. Under the same conditions, different solutions of ampicillin (antibacterial) and cycloheximide (antifungal) were used as standards. The assays with the standards were carried out using also DMSO solutions, which was chosen as the best solvent. After comparative toxicity assays this solvent was shown to be nontoxic. The MIC was considered to be the lowest concentration of the tested sample able to inhibit the growth of bacteria or fungi, after $24 \mathrm{~h}$. The diameters of the inhibition zones corresponding to the MICs were measured using a ruler, with an accuracy of $0.5 \mathrm{~mm}$. Each inhibition zone diameter was measured three times (three different plates) and the average was calculated. A control using only inoculation was also carried out.

\subsection{Effect of nitrogen source on antioxidant activity}

\subsubsection{Standards and reagents}

Standards BHA (2-tert-butyl-4-methoxyphenol), TBHQ (tert-butylhydroquinone), L-ascorbic acid, $\alpha$-tocopherol, gallic acid and $(+)$-catechin were purchase from Sigma (St. Louis, MO, USA). 2,2-diphenyl-1-picrylhydrazyl (DPPH) was obtained from Alfa Aesar (Ward Hill, MA, USA). All other chemicals were obtained from the Sigma Chemical Co. (St. Louis, MO, USA). Methanol was obtained from Pronalab (Lisbon, Portugal). Water was treated in a Mili-Q water purification system (TGI Pure Water Systems, USA).

\subsubsection{Determination of antioxidant components}

For phenolic contents determination $1 \mathrm{ml}$ of sample was mixed with $1 \mathrm{ml}$ of Folin and Ciocalteu's phenol reagent (Singleton \& Rossi, 1965). After $3 \mathrm{~min}, 1 \mathrm{ml}$ of saturated sodium carbonate solution was added to the mixture and diluted to $10 \mathrm{ml}$ with distilled water. The reaction was kept in the dark for $90 \mathrm{~min}$, after which the absorbance was read at $725 \mathrm{~nm}$ (Analytikijena 200-2004 spectrophotometer). Gallic acid was used to calculate the standard curve (0.01-0.4 mM; $\left.\quad Y=2.8557 X-0.0021 ; R^{2}=0.9999\right)$ and the results were expressed as $\mathrm{mg}$ of gallic acid equivalents (GAEs) per g of extract.

For flavonoid contents determination (Jia, Tang, \& Wu, $1999)$ the mycelium extract $(250 \mu \mathrm{L})$ was mixed with $1.25 \mathrm{ml}$ of distilled water and $75 \mu \mathrm{L}$ of a $5 \% \mathrm{NaNO}_{2}$ solution. After $5 \mathrm{~min}, 150 \mu \mathrm{L}$ of a $10 \% \mathrm{AlCl}_{3} \cdot \mathrm{H}_{2} \mathrm{O}$ solution was added. After $6 \mathrm{~min}, 500 \mu \mathrm{L}$ of $1 \mathrm{M} \mathrm{NaOH}$ and $275 \mu \mathrm{L}$ of distilled water were added to the mixture. The solution was mixed well and the intensity of the pink colour was measured at $510 \mathrm{~nm} .(+)$-catechin was used to calculate the standard curve $\quad\left(0.022-0.34 \mathrm{mM} ; \quad Y=0.9629 X-0.0002 ; \quad R^{2}=\right.$ $0.9999)$ and the results were expressed as $\mathrm{mg}$ of $(+)$-catechin equivalents (CEs) per $\mathrm{g}$ of extract.

\subsubsection{DPPH radical-scavenging activity}

Various concentrations of mycelium extracts $(0.3 \mathrm{ml})$ were mixed with $2.7 \mathrm{ml}$ of methanolic solution containing DPPH radicals $\left(6 \times 10^{-5} \mathrm{~mol} / \mathrm{L}\right)$ (Hatano, Kagawa, Yasuhara, \& Okuda, 1988). The mixture was shaken vigorously and left to stand for 60 min in the dark (until stable absorption values were obtained). The reduction of the DPPH radical was determined by measuring the absorption at $517 \mathrm{~nm}$. The radical scavenging activity (RSA) was calculated as a percentage of DPPH discolouration using the equation: $\% \mathrm{RSA}=\left[\left(A_{\mathrm{DPPH}}-A_{\mathrm{S}}\right) / A_{\mathrm{DPPH}}\right] \times 100$, where $A_{\mathrm{S}}$ is the absorbance of the solution when the sample extract has been added at a particular level, and $A_{\mathrm{DPPH}}$ is the absorbance of the DPPH solution. The extract concentration providing $50 \%$ inhibition $\left(\mathrm{EC}_{50}\right)$ was calculated from the graph of RSA percentage against extract concentration. BHA and $\alpha$-tocopherol were used as standards.

\subsubsection{Reducing power}

Various concentrations of mycelium methanolic extracts $(2.5 \mathrm{ml})$ were mixed with $2.5 \mathrm{ml}$ of $200 \mathrm{mmol} / \mathrm{L}$ sodium phosphate buffer ( $\mathrm{pH} 6.6$ ) and $2.5 \mathrm{ml}$ of $1 \%$ potassium ferricyanide (Oyaizu, 1986). The mixture was incubated at $50{ }^{\circ} \mathrm{C}$ for $20 \mathrm{~min}$. After $2.5 \mathrm{ml}$ of $10 \%$ trichloroacetic acid (w/v) was added, the mixture was centrifuged at $1000 \mathrm{rpm}$ for 8 min (Centorion K24OR-2003 refrigerated centrifuge). The supernatant $(5 \mathrm{ml})$ was mixed with $5 \mathrm{ml}$ of deionised water and $1 \mathrm{ml}$ of $0.1 \%$ of ferric chloride, and the absorbance was measured spectrophotometrically at $700 \mathrm{~nm}$. The extract concentration providing 50\% absorbance $\left(\mathrm{EC}_{50}\right)$ was calculated from the graph at $700 \mathrm{~nm}$ against extract concentration. BHA and $\alpha$-tocopherol were used as standards.

\subsubsection{Inhibition of erythrocyte hemolysis mediated by peroxyl free radicals}

The antioxidant activity of the mycelium extracts was measured as the inhibition of erythrocyte hemolysis (Zhang 
et al., 1997). Blood was obtained from male ram (churra galega transmontana) of body weight $\sim 67 \mathrm{~kg}$. Erythrocytes separated from the plasma and the buffy coat were washed three times with $10 \mathrm{ml}$ of $10 \mathrm{mM}$ phosphate buffer saline (PBS) at pH 7.4 (prepared by mixing $10 \mathrm{mM}$ of $\mathrm{NaH}_{2} \mathrm{PO}_{4}$ and $\mathrm{Na}_{2} \mathrm{HPO}_{4}$, and $125 \mathrm{mM}$ of $\mathrm{NaCl}$ in 11 of distilled water) and centrifuged at $1500 \mathrm{~g}$ for $5 \mathrm{~min}$. During the last washing, the erythrocytes were obtained by centrifugation at $1500 \mathrm{~g}$ for $10 \mathrm{~min}$. A $0.1 \mathrm{ml}$ of a $20 \%$ suspension of eryth-

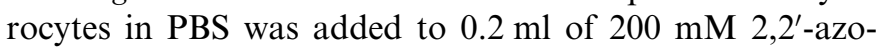
bis(2-amidinopropane)dihydrochloride (AAPH) solution (in PBS) and $0.1 \mathrm{ml}$ of mycelium methanolic extracts of different concentrations. The reaction mixture was shaken gently $(30 \mathrm{rpm})$ while being incubated at $37^{\circ} \mathrm{C}$ for $3 \mathrm{~h}$. The reaction mixture was diluted with $8 \mathrm{ml}$ of PBS and centrifuged at $3000 \mathrm{~g}$ for $10 \mathrm{~min}$, the absorbance of its supernatant was then read at $540 \mathrm{~nm}$ by a spectrophotometer, after filtration with a syringe filter (cellulose membrane $30 \mathrm{~mm}, 0.20 \mu \mathrm{m}$, Titan). The percentage hemolysis inhibition was calculated by the equation $\%$ hemolysis inhibition $=\left[\left(A_{\mathrm{AAPH}}-A_{\mathrm{S}}\right) / A_{\mathrm{AAPH}}\right] \times 100$, where $A_{\mathrm{S}}$ is the absorbance of the sample containing the mycelium extract, and $A_{\mathrm{AAPH}}$ is the absorbance of the control sample containing no mushroom extract. The extract concentration providing $50 \%$ inhibition $\left(\mathrm{EC}_{50}\right)$ was calculated from the graph of hemolysis inhibition percentage against extract concentration. L-ascorbic acid was used as standard.

\subsubsection{Inhibition of lipid peroxidation using the $\beta$-carotene linoleate model system}

The antioxidant activity of mushroom extracts was evaluated by the $\beta$-carotene linoleate model system (Mi-Yae, Tae-Hun, \& Nak-Ju, 2003). A solution of $\beta$-carotene was prepared by dissolving $2 \mathrm{mg}$ of $\beta$-carotene in $10 \mathrm{ml}$ of chloroform. Two millilitres of this solution was pipetted into a $100 \mathrm{ml}$ round-bottom flask. After the chloroform was removed at $40^{\circ} \mathrm{C}$ under vacuum, $40 \mathrm{mg}$ of linoleic acid, $400 \mathrm{mg}$ of Tween 80 emulsifier, and $100 \mathrm{ml}$ of distilled water were added to the flask with vigorous shaking. Aliquots $(4.8 \mathrm{ml})$ of this emulsion were transferred into different test tubes containing $0.2 \mathrm{ml}$ of the mycelium extracts at different concentrations. The tubes were shaken and incubated at $50{ }^{\circ} \mathrm{C}$ in a water bath. As soon as the emulsion was added to each tube, the zero time absorbance was measured at $470 \mathrm{~nm}$ using a spectrophotometer. Absorbance readings were then recorded at $20 \mathrm{~min}$ intervals until the control sample had changed colour. A blank, devoid of $\beta$-carotene, was prepared as a background measurement. Lipid peroxidation (LPO) inhibition was calculated using the following equation: LPO inhibition $=(\beta$-carotene content after $2 \mathrm{~h}$ of assay/initial $\beta$-carotene content $) \times 100$. The extract concentration providing $50 \%$ antioxidant activity $\left(\mathrm{EC}_{50}\right)$ was calculated from the graph of antioxidant activity percentage against extract concentration. TBHQ was used as standard.

\subsection{Statistical analysis}

All the assays were carried out in triplicate and the results are expressed as mean values and standard error or standard deviation (SD). Differences among means were done by analysis of variance (ANOVA), using SAS v. 9.1.3, and averages were compared using Tukey test $(p<0.05)$.

\section{Results and discussion}

\subsection{Effect of nitrogen source on mycelia growth rate}

The L. giganteus mycelium growth $(\mathrm{dw})$ in liquid medium with different nitrogen sources is shown in Fig. 1. The mycelium growth did not significantly vary with the nitrogen source used. The use of $\left(\mathrm{NH}_{4}\right)_{2} \mathrm{HPO}_{4}$, did not lead to a higher mycelium yield although hydrogenophosphate salts had been referred to as the most suitable nitrogen source for mycelium growth for a majority of mushrooms (Mao \& Zhong, 2006). The mycelium growth in the presence of $\mathrm{KNO}_{3}, \mathrm{NH}_{4} \mathrm{NO}_{3}$ and $\left(\mathrm{NH}_{4}\right)_{2} \mathrm{HPO}_{4}$ significantly increased until 15 days of incubation after which maintaining significant growth $(p<0.05)$. In the case of $\mathrm{NaNO}_{2}$ the mycelium growth increased significantly until 45 days $(0.095 \pm 0.0135 \mathrm{~g})$, remaining at a similar dry weight $(p>0.05)$ until 60 days of growth.

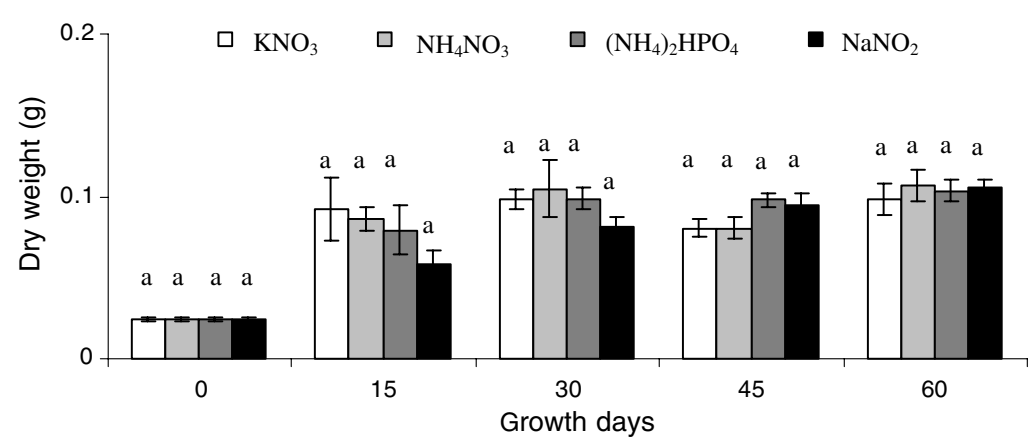

Fig. 1. Mycelium growth (dw) of Leucopaxillus giganteus in the presence of different nitrogen sources. In each growth time different letters mean significant differences $(p<0.05)$. 


\subsection{Effect of nitrogen source on antimicrobial activity}

The mycelia samples were screened for their antimicrobial properties against $B$. cereus, B. subtilis, S. aureus, $E$. coli, $P$. aeruginosa, $K$. pneumoniae, $C$. albicans and $C$. neoformans. The minimal inhibitory concentration (MIC) values for the tested bacteria and fungi (Table 1) were determined as an evaluation of the antimicrobial activity of the samples.

Despite all the mycelia obtained, in the presence of different nitrogen sources, revealing antimicrobial activity, the response for each microorganism tested was different. The extracts presented similar antimicrobial capacity, inhibiting only Gram positive bacteria and in the order $S$. aureus $>B$. cereus $>B$. subtilis. These results are in agreement with a previous study from our research group (Barros et al., in press) on the antimicrobial activity of three wild edible mushrooms, (Lactarius deliciosus, Sarcodon imbricatus and Tricholoma portentosum) where the growth of Gram positive bacteria was well inhibited. Herein, $S$. aureus was the most susceptible microorganism, presenting MICs of 3.12 and $6.25 \mathrm{mg} / \mathrm{ml}$ for the mycelia obtained in the presence of $\left(\mathrm{NH}_{4}\right)_{2} \mathrm{HPO}_{4}$ and for other nitrogen sources, respectively. These results are particularly important considering that $S$. aureus can produce several types of enterotoxins that cause gastroenteritis, which is a major food-borne disease in most countries. Additionally, this species is exceptionally resistance to a number of phytochemicals (Halpin-Dohnalek \& Marth, 1989). The tested Gram negative bacteria (E. coli, P. aeruginosa and $K$. peumoniae) and fungi ( $C$. albicans and $C$. neoformans) species were resistant to all samples. $\left(\mathrm{NH}_{4}\right)_{2} \mathrm{HPO}_{4}$ proved to be the most promising nitrogen source to produce bioactive compounds that inhibit Gram

Table 1

Antimicrobial activity of mycelia extracts obtained using different nitrogen sources after 15 and 60 days of growth

\begin{tabular}{|c|c|c|c|c|c|c|c|c|}
\hline \multirow[t]{2}{*}{ Nitrogen source } & \multicolumn{8}{|c|}{$\mathrm{MIC}(\mathrm{mg} / \mathrm{ml})$} \\
\hline & B. cereus & B. subtilis & S. aureus & P. aeruginosa & E. coli & K. peumoniae & C. albicans & C. neoformans \\
\hline $\mathrm{KNO}_{3}, 15$ days & $\begin{array}{l}12.5 \\
(+++)\end{array}$ & $\begin{array}{l}25 \\
(++)\end{array}$ & $\begin{array}{l}6.25 \\
(++++)\end{array}$ & $\begin{array}{l}25 \\
(-)\end{array}$ & $\begin{array}{l}25 \\
(-)\end{array}$ & $\begin{array}{l}25 \\
(-)\end{array}$ & $\begin{array}{l}25 \\
(-)\end{array}$ & $\begin{array}{l}25 \\
(-)\end{array}$ \\
\hline $\mathrm{KNO}_{3}, 60$ days & $\begin{array}{l}12.5 \\
(+++)\end{array}$ & $\begin{array}{l}25 \\
(++)\end{array}$ & $\begin{array}{l}6.25 \\
(++++)\end{array}$ & $\begin{array}{l}25 \\
(-)\end{array}$ & $\begin{array}{l}25 \\
(-)\end{array}$ & $\begin{array}{l}25 \\
(-)\end{array}$ & $\begin{array}{l}25 \\
(-)\end{array}$ & $\begin{array}{l}25 \\
(-)\end{array}$ \\
\hline $\mathrm{NH}_{4} \mathrm{NO}_{3}, 15$ days & $\begin{array}{l}12.5 \\
(+++)\end{array}$ & $\begin{array}{l}25 \\
(++)\end{array}$ & $\begin{array}{l}3.13 \\
(++++)\end{array}$ & $\begin{array}{l}25 \\
(-)\end{array}$ & $\begin{array}{l}25 \\
(-)\end{array}$ & $\begin{array}{l}25 \\
(-)\end{array}$ & $\begin{array}{l}25 \\
(-)\end{array}$ & $\begin{array}{l}25 \\
(-)\end{array}$ \\
\hline $\mathrm{NH}_{4} \mathrm{NO}_{3}, 60$ days & $\begin{array}{l}12.5 \\
(+++)\end{array}$ & $\begin{array}{l}25 \\
(++)\end{array}$ & $\begin{array}{l}3.13 \\
(++++)\end{array}$ & $\begin{array}{l}25 \\
(-)\end{array}$ & $\begin{array}{l}25 \\
(-)\end{array}$ & $\begin{array}{l}25 \\
(-)\end{array}$ & $\begin{array}{l}25 \\
(-)\end{array}$ & $\begin{array}{l}25 \\
(-)\end{array}$ \\
\hline$\left(\mathrm{NH}_{4}\right)_{2} \mathrm{HPO}_{4}, 15$ days & $\begin{array}{l}12.5 \\
(++++)\end{array}$ & $\begin{array}{l}25 \\
(++)\end{array}$ & $\begin{array}{l}6.25 \\
(++++)\end{array}$ & $\begin{array}{l}25 \\
(-)\end{array}$ & $\begin{array}{l}25 \\
(-)\end{array}$ & $\begin{array}{l}25 \\
(-)\end{array}$ & $\begin{array}{l}25 \\
(-)\end{array}$ & $\begin{array}{l}25 \\
(-)\end{array}$ \\
\hline$\left(\mathrm{NH}_{4}\right)_{2} \mathrm{HPO}_{4}, 60$ days & $\begin{array}{l}12.5 \\
(++++)\end{array}$ & $\begin{array}{l}25 \\
(++)\end{array}$ & $\begin{array}{l}6.25 \\
(++++)\end{array}$ & $\begin{array}{l}25 \\
(-)\end{array}$ & $\begin{array}{l}25 \\
(-)\end{array}$ & $\begin{array}{l}25 \\
(-)\end{array}$ & $\begin{array}{l}25 \\
(-)\end{array}$ & $\begin{array}{l}25 \\
(-)\end{array}$ \\
\hline $\mathrm{NaNO}_{2}, 15$ days & $\begin{array}{l}25 \\
(+)\end{array}$ & $\begin{array}{l}25 \\
(+)\end{array}$ & $\begin{array}{l}6.25 \\
(+++)\end{array}$ & $\begin{array}{l}25 \\
(-)\end{array}$ & $\begin{array}{l}25 \\
(-)\end{array}$ & $\begin{array}{l}25 \\
(-)\end{array}$ & $\begin{array}{l}25 \\
(-)\end{array}$ & $\begin{array}{l}25 \\
(-)\end{array}$ \\
\hline $\mathrm{NaNO}_{2}, 60$ days & $\begin{array}{l}25 \\
(+)\end{array}$ & $\begin{array}{l}25 \\
(+)\end{array}$ & $\begin{array}{l}6.25 \\
(+++)\end{array}$ & $\begin{array}{l}25 \\
(-)\end{array}$ & $\begin{array}{l}25 \\
(-)\end{array}$ & $\begin{array}{l}25 \\
(-)\end{array}$ & $\begin{array}{l}25 \\
(-)\end{array}$ & $\begin{array}{l}25 \\
(-)\end{array}$ \\
\hline
\end{tabular}

No antimicrobial activity $(-)$, inhibition zone $<1 \mathrm{~mm}$. Slight antimicrobial activity $(+)$, inhibition zone $2-3 \mathrm{~mm}$. Moderate antimicrobial activity $(++)$, inhibition zone 4-5 mm. High antimicrobial activity $(+++)$, inhibition zone $6-9 \mathrm{~mm}$. Strong antimicrobial activity $(++++)$, inhibition zone $>9$ mm. Standard deviation $\pm 0.5 \mathrm{~mm}$.

Table 2

Contents of total flavonoids and phenols (mg/g) of mycelium extracts obtained using different nitrogen sources after $15,30,45$ and 60 days of growth

\begin{tabular}{|c|c|c|c|c|}
\hline & $\mathrm{KNO}_{3}$ & $\mathrm{NH}_{4} \mathrm{NO}_{3}$ & $\left(\mathrm{NH}_{4}\right)_{2} \mathrm{HPO}_{4}$ & $\mathrm{NaNO}_{2}$ \\
\hline \multicolumn{5}{|l|}{15 Days } \\
\hline Flavonoids & $0.69 \pm 0.09 \mathrm{a}$ & $0.57 \pm 0.03 \mathrm{~b}$ & $0.63 \pm 0.11 \mathrm{ba}$ & $0.47 \pm 0.03 \mathrm{c}$ \\
\hline Phenols & $6.21 \pm 0.18 b$ & $5.5 \pm 0.52 \mathrm{~b}$ & $9.33 \pm 0.92 \mathrm{a}$ & $3.27 \pm 0.41 \mathrm{c}$ \\
\hline \multicolumn{5}{|l|}{30 Days } \\
\hline Flavonoids & $0.81 \pm 0.02 \mathrm{~b}$ & $1.07 \pm 0.06 \mathrm{a}$ & $0.88 \pm 0.09 \mathrm{~b}$ & $0.87 \pm 0.09 \mathrm{~b}$ \\
\hline Phenols & $8.59 \pm 0.5 \mathrm{~d}$ & $12.07 \pm 0.82 \mathrm{c}$ & $17.03 \pm 0.64 \mathrm{a}$ & $16.17 \pm 0.56 b$ \\
\hline \multicolumn{5}{|l|}{45 Days } \\
\hline Flavonoids & $1.12 \pm 0.02 \mathrm{a}$ & $0.74 \pm 0.08 \mathrm{~b}$ & $1.14 \pm 0.02 \mathrm{a}$ & $1.09 \pm 0.19 \mathrm{a}$ \\
\hline Phenols & $21.9 \pm 0.13 \mathrm{~b}$ & $11.2 \pm 0.23 \mathrm{~d}$ & $22.7 \pm 0.67 \mathrm{a}$ & $16.9 \pm 1.08 \mathrm{c}$ \\
\hline \multicolumn{5}{|l|}{60 Days } \\
\hline Flavonoids & $1.01 \pm 0.07 \mathrm{~d}$ & $1.12 \pm 0.07 \mathrm{c}$ & $1.35 \pm 0.07 \mathrm{a}$ & $1.23 \pm 0.04 \mathrm{~b}$ \\
\hline Phenols & $19.6 \pm 0.66 \mathrm{c}$ & $13.7 \pm 1.88 \mathrm{~d}$ & $23.4 \pm 2.05 \mathrm{a}$ & $21.9 \pm 1.46 \mathrm{~b}$ \\
\hline
\end{tabular}

In each row different letters mean significant differences $(p<0.05)$. 
positive bacteria growth, presenting lower MICs and higher growth inhibition zones.

\subsection{Effect of nitrogen source on antioxidant activity}

Table 2 shows the phenol and flavonoid concentration in the mycelium extracts obtained in the presence of four
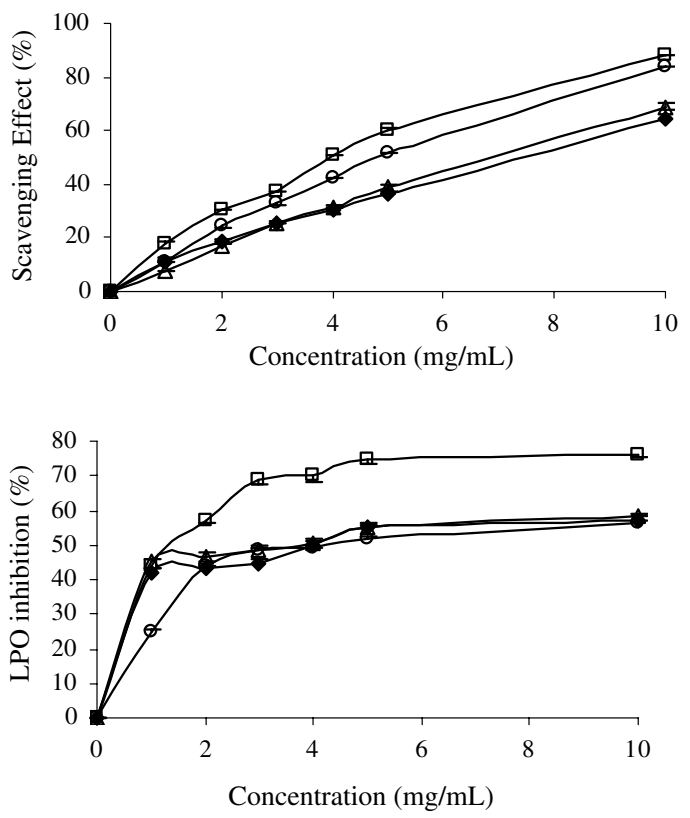

$\rightarrow \mathrm{KNO}_{3} \quad \triangle \quad \mathrm{NH}_{4} \mathrm{NO}_{3}$

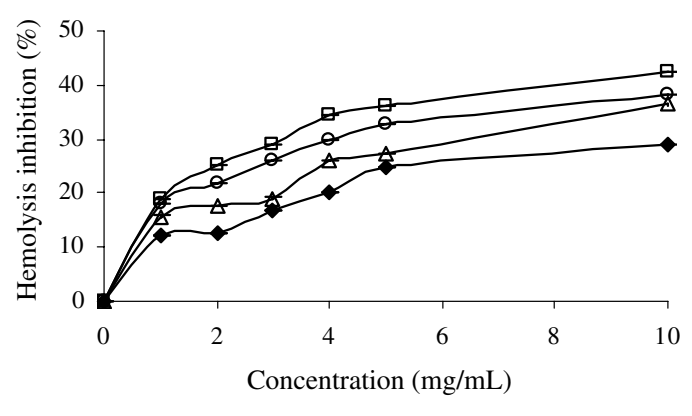

different nitrogen sources: $\mathrm{KNO}_{3}, \mathrm{NH}_{4} \mathrm{NO}_{3},\left(\mathrm{NH}_{4}\right)_{2} \mathrm{HPO}_{4}$ and $\mathrm{NaNO}_{2}$. $\left(\mathrm{NH}_{4}\right)_{2} \mathrm{HPO}_{4}$ proved to be the best nitrogen source for the synthesis of phenols and flavonoids compounds, showing the highest content at all growth times $(23.36 \pm 2.05$ and $1.35 \pm 0.07 \mathrm{mg} / \mathrm{g}$, respectively after 60 days of growth). The amount of this phenol was higher than the value found in the fresh mushroom as we had

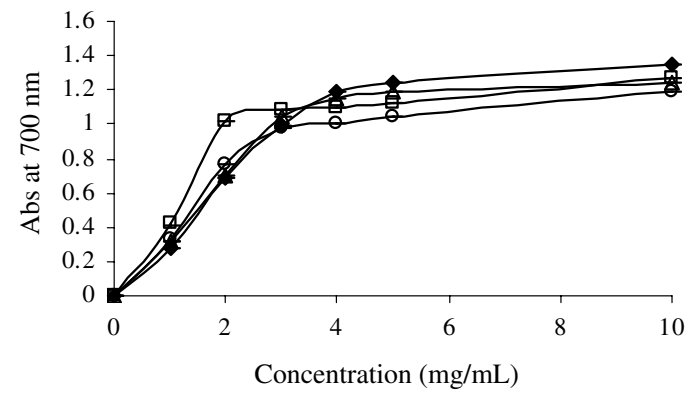

$\begin{array}{llll}\left(\mathrm{NH}_{4}\right)_{2} \mathrm{HPO}_{4} \quad \longrightarrow \mathrm{NaNO}_{2} & \longrightarrow\end{array}$

Fig. 2. Antioxidant activity of Leucopaxillus giganteus mycelia after 30 days of growth: scavenging activity on DPPH radicals (\%), reducing power, hemolysis inhibition (\%) and lipid peroxidation (LPO) inhibition (\%).

Table 3

$\mathrm{EC}_{50}$ values obtained in the antioxidant activity assays of mycelium extracts grown in the presence of different nitrogen sources after $15,30,45$ and 60 days of growth

\begin{tabular}{|c|c|c|c|c|}
\hline $\mathrm{EC}_{50}(\mathrm{mg} / \mathrm{ml})$ & $\mathrm{KNO}_{3}$ & $\mathrm{NH}_{4} \mathrm{NO}_{3}$ & $\left(\mathrm{NH}_{4}\right)_{2} \mathrm{HPO}_{4}$ & $\mathrm{NaNO}_{2}$ \\
\hline \multicolumn{5}{|l|}{15 Days } \\
\hline Scavenging effect & $9.31 \pm 0.12 \mathrm{c}$ & $9.48 \pm 0.09 \mathrm{~b}$ & $6.29 \pm 0.14 \mathrm{~d}$ & $>10.0 \mathrm{a}$ \\
\hline Reducing power & $1.76 \pm 0.001 \mathrm{c}$ & $1.98 \pm 0.01 \mathrm{~b}$ & $1.29 \pm 0.01 \mathrm{~d}$ & $3.33 \pm 0.02 \mathrm{a}$ \\
\hline Hemolysis inhibition & $>10.0$ & $>10.0$ & $>10.0$ & $>10.0$ \\
\hline LPO inhibition & $8.79 \pm 0.89 \mathrm{a}$ & $8.97 \pm 0.48 \mathrm{a}$ & $5.67 \pm 0.47 \mathrm{~b}$ & $>10.0 \mathrm{a}$ \\
\hline \multicolumn{5}{|l|}{30 Days } \\
\hline Scavenging effect & $7.48 \pm 0.33 \mathrm{a}$ & $6.85 \pm 0.13 \mathrm{~b}$ & $3.97 \pm 0.04 \mathrm{~d}$ & $4.79 \pm 0.04 \mathrm{c}$ \\
\hline Reducing power & $1.54 \pm 0.002 \mathrm{a}$ & $1.47 \pm 0.01 \mathrm{~b}$ & $1.14 \pm 0.001 \mathrm{~d}$ & $1.4 \pm 0.001 \mathrm{c}$ \\
\hline Hemolysis inhibition & $>10.0$ & $>10.0$ & $>10.0$ & $>10.0$ \\
\hline LPO inhibition & $4.07 \pm 0.02 \mathrm{a}$ & $3.73 \pm 0.14 \mathrm{ba}$ & $1.41 \pm 0.42 \mathrm{c}$ & $3.32 \pm 0.07 \mathrm{~b}$ \\
\hline \multicolumn{5}{|l|}{45 Days } \\
\hline Scavenging effect & $4.14 \pm 0.09 \mathrm{c}$ & $8.67 \pm 0.06 \mathrm{a}$ & $2.98 \pm 0.02 \mathrm{~d}$ & $4.46 \pm 0.06 \mathrm{~b}$ \\
\hline Reducing power & $1.02 \pm 0.003 \mathrm{c}$ & $1.9 \pm 0.004 \mathrm{a}$ & $0.9 \pm 0.004 \mathrm{~d}$ & $1.04 \pm 0.01 \mathrm{~b}$ \\
\hline Hemolysis inhibition & $>10.0$ & $>10.0$ & $>10.0$ & $>10.0$ \\
\hline LPO inhibition & $1.28 \pm 0.45 \mathrm{cb}$ & $3.74 \pm 0.07 \mathrm{a}$ & $1.23 \pm 0.44 \mathrm{c}$ & $2.1 \pm 0.14 \mathrm{~b}$ \\
\hline \multicolumn{5}{|l|}{60 Days } \\
\hline Scavenging effect & $4.33 \pm 0.19 b$ & $4.72 \pm 0.22 \mathrm{a}$ & $2.95 \pm 0.07 \mathrm{c}$ & $2.85 \pm 0.04 \mathrm{c}$ \\
\hline Reducing power & $1.3 \pm 0.01 \mathrm{~b}$ & $1.3 \pm 0.01 \mathrm{a}$ & $0.99 \pm 0.001 \mathrm{c}$ & $0.96 \pm 0.01 \mathrm{~d}$ \\
\hline Hemolysis inhibition & $>10.0$ & $>10.0$ & $>10.0$ & $>10.0$ \\
\hline LPO inhibition & $1.58 \pm 0.2 \mathrm{~b}$ & $2.6 \pm 0.06 \mathrm{a}$ & $1.31 \pm 0.03 \mathrm{~b}$ & $1.47 \pm 0.1 \mathrm{~b}$ \\
\hline
\end{tabular}

In each row different letters mean significant differences $(p<0.05)$. 
already described in a previous study (Barros et al., in press). The amount found in the other extracts (13.71 to $21.93 \mathrm{mg} / \mathrm{g})$ was significantly $(p<0.05)$ lower than the content found in the first case. For almost all of the nitrogen sources, the antioxidant component content increased along the growth time. This is probably a response to the oxidative stress, and therefore free radical production (Anderson, 1996), related to the mycelium growth.

The higher content of these antioxidant compounds in the mycelium extract grown in the presence of ammonium hydrogenophosphate might account for the better results found in their antioxidant activity.

As an example of the results obtained we present in Fig. 2 the scavenging activity on DPPH radicals, reducing power, hemolysis inhibition and LPO inhibition by $\beta$-carotene bleaching method of the mycelium extracts after 30 days of growth. For an overview of the results, we present in Table 3 the $\mathrm{EC}_{50}$ values for the antioxidant activity assays obtained from each mycelium methanolic extract, after 15, 30, 45, and 60 days of growth. At all the growth times, $\left(\mathrm{NH}_{4}\right)_{2} \mathrm{HPO}_{4}$ revealed better antioxidant properties (significantly lower $\mathrm{EC}_{50}$ values; $p<0.05$ ) than the other nitrogen sources, which is in agreement with the higher content of phenols and flavonoids found in the first case. The $\mathrm{EC}_{50}$ values obtained for the reducing power and the LPO inhibition were better than for scavenging effects on DPPH radicals and for the hemolysis inhibition mediated by peroxyl free radicals. In the last case, $\mathrm{EC}_{50}$ values were always higher than $10 \mathrm{mg} / \mathrm{ml}$.

Significantly negative linear correlations were established between the phenols and flavonoids content, and $\mathrm{EC}_{50}$ values of DPPH scavenging activity (determination coefficient 0.877 for phenols and 0.678 for flavonoids; $p<0.001$ ), reducing power (determination coefficient 0.626 for phenols and 0.521 for flavonoids; $p<0.001$ ) and LPO inhibition (determination coefficient 0.807 for phenols and 0.669 for flavonoids, $p<0.001$ ) (Fig. 3). These negative linear correlations prove that the sample with the highest phenol content (ammonium hydrogenophosphate as nitrogen source) shows higher antioxidant activity and lower $\mathrm{EC}_{50}$ values, while the sample with the lowest phenol content (ammonium nitrate as nitrogen source) presents lower antioxidant activity and higher $\mathrm{EC}_{50}$ values.

In conclusion, the results obtained in this study demonstrate that not only mushrooms but also their mycelia may be a good candidate for employment as an antimicrobial agent against bacteria responsible for human gastrointestinal and respiratory tract infections. Mushroom mycelia may also constitute a good source of healthy compounds, namely phenols and flavonoids, suggesting that it could be useful in the prevention of diseases in which free radicals are implicated. To our best knowledge, the present study was the first report to demonstrate that the bioactive properties (antimicrobial and antioxidant activities), and nutraceuticals production of mushroom mycelia depend on the nitrogen source used for the mycelium growth.
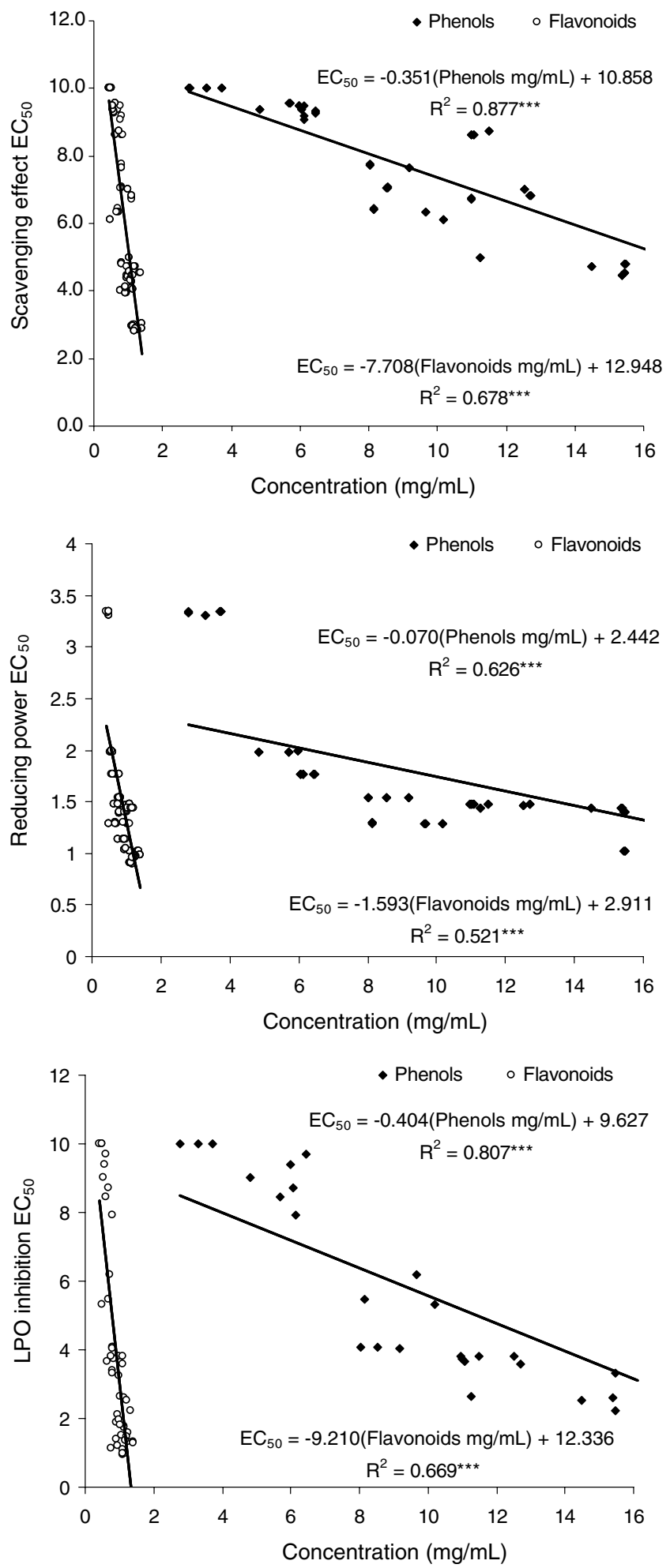

Fig. 3. Correlation established between total phenols and flavonoids content, and scavenging effect on DPPH radicals, reducing power and LPO inhibition.

\section{Acknowledgement}

The authors are grateful to Foundation for Science and Technology (POCI/AGR/56661/2004) for financial support of this work. 


\section{References}

Anderson, D. (1996). Antioxidant defences against reactive oxygen species causing genetic and other damage (Vol. 350). Amsterdam: Mutation Research.

Barros, L., Calhelha, R. C., Vaz, J. A., Ferreira, I. C. F. R., Baptista, P., \& Estevinho, L.M. (in press). Antimicrobial activity and bioactive compounds of Portuguese wild edible mushrooms. European Food Research and Technology.

Barros, L., Ferreira, M.-J., Queirós, B., Ferreira, I. C. F. R., \& Baptista, P. (2007). Total phenols, ascorbic acid, $\beta$-carotene and lycopene in Portuguese wild edible mushrooms and their antioxidant activities. Food Chemistry, 103, 413-419.

Borchers, A. T., Keen, C. L., \& Gershwin, M. E. (2004). Mushroom, tumors, and immunity: An update. Experimental Biology and Medicine, 229, 393-406.

Breitenbach, J., \& Kränzlin, F. (1991). Champignons de Suisse. Boletus et champignons à lames (pp. 216). Nykologia Lucerne Ed.

Brundrett, M., Bougher, N., Dell, B., Grove, T., \& Malajczuk, N. (1996). Working with mycorrhizas in forestry and agriculture. ACIAR monograph.

Cheung, L. M., \& Cheung, P. C. K. (2005). Mushroom extracts with antioxidant activity against lipid peroxidation. Food Chemistry, 89, 403-409.

Cho, Y. J., Park, J. P., Hwang, H. J., Kim, S. W., Choi, J. W., \& Yun, J. W. (2002). Production of red pigment by submerged culture of Paecilomyces sinclairii. Letters in Applied Microbiology, 35, 195-202.

Fan, L., Soccol, A. T., Pandey, A., \& Soccol, C. R. (2007). Effect of nutritional and environmental conditions on the production of exopolysaccharide of Agaricus brasiliensis by submerged fermentation and its antitumor activity. LWT. Food Science and Technology, 40, 30-35.

Fasidi, I. O., \& Akwakwa, D. O. (1996). Growth requirements of Volvariella apeciosa (Fr. Ex. Fr.) Sing., a Nigerian mushroom. Food Chemistry, 55, 165-168.

Ferreira, I. C. F. R., Baptista, P., Vilas-Boas, M., \& Barros, L. (2007). Free-radical scavenging capacity and reducing power of wild edible mushrooms from northeast Portugal. Food Chemistry, 100, 1511-1516.

Ferreira, I. C. F. R., Calhelha, R. C., Estevinho, L. M., \& Queiroz, M.-J. R. P. (2004). Screening of antimicrobial activity of diarylamines in the 2,3,5-trimethylbenzo[b]thiophene series: A structure-activity evaluation study. Bioorganic and Medicinal Chemistry Letters, 14, 5831-5833.

Gbolagade, J. S., Fasidi, I. O., Ajayi, E. J., \& Sobowale, A. A. (2006). Effect of physico-chemical factors and semi-synthetic media on vegetative growth of Lentinus subnudus (Berk.), an edible mushroom from Nigeria. Food Chemistry, 99, 742-747.

Halpin-Dohnalek, M. I., \& Marth, E. H. (1989). Growth and production of enterotoxin A by Staphylococcus aureus in cream. Journal of Dairy Sciences, 72, 2266-2275

Hatano, T., Kagawa, H., Yasuhara, T., \& Okuda, T. (1988). Two new flavonoids and other constituents in licorice root: Their relative astringency and radical scavenging effects. Chemical Pharmaceutical Bulletin, 36, 2090-2097.

Hawkey, P. M., \& Lewis, D. A. (1994). Medical bacteriology - A practical approach. UK: Oxford University.

Jia, Z., Tang, M., \& Wu, J. (1999). The determination of flavonoid contents in mulberry and their scavenging effects on superoxide radicals. Food Chemistry, 64, 555-559.

Jonathan, S. G., \& Fasidi, I. O. (2001). Effect of carbon, nitrogen and mineral sources on growth of Psathyerella atroumbonata (Pegler), a Nigerian edible mushroom. Food Chemistry, 72, 479-483.

Lindequist, U., Niedermeyer, T. H. J., \& Jülich, W.-D. (2005). The pharmacological potential of mushrooms. eCAM, 2, 285-299.

Mao, X.-B., \& Zhong, J.-J. (2006). Significant effect of $\mathrm{NH}_{4}^{+}$on cordycepin production by submerged cultivation of medicinal mushroom Cordyceps militaris. Enzyme and Microbial Technology, 38, 343-350.

Mau, J.-L., Chang, C.-N., Huang, S.-J., \& Chen, C.-C. (2004). Antioxidant properties of methanolic extracts from Grifola frondosa, Morchella esculenta and Termitomyces albuminosus mycelia. Food Chemistry, $87,111-118$

Mi-Yae, S., Tae-Hun, K., \& Nak-Ju, S. (2003). Antioxidants and free radical scavenging activity of Phellinus baumii (Phellinus of Hymenochaetaceae) extracts. Food Chemistry, 82, 593-597.

Oyaizu, M. (1986). Studies on products of browning reactions: Antioxidative activities of products of browning reaction prepared from glucosamine. Japanese Journal of Nutrition, 44, 307-315.

Singleton, V. L., \& Rossi, J. A. Jr., (1965). Colorimetric of total phenolics with phosphomolybdic-phosphotungstic acid reagents. American Journal of Enology and Viticulture, 16, 144-158.

Wasser, S. P., Elisashvili, V. I., \& Tan, K. K. (2003). Effects of carbon and nitrogen sources in the medium on Tremella mesenterica Retz.: Fr. (Heterobasidiomycetes) growth and polysaccharide production. International Journal of Medicinal Mushrooms, 5, 49-56.

Wu, J.-Z., Cheung, P. C. K., Wong, K.-H., \& Huang, N.-L. (2003). Studies on submerged fermentation of Pleurotus tuber-regium (Fr.) Singer-Part 1: Physical and chemical factors affecting the rate of mycelial growth and bioconversion efficiency. Food Chemistry, 81, 389-393.

Wu, J.-Z., Cheung, P. C. K., Wong, K.-H., \& Huang, N.-L. (2004). Studies on submerged fermentation of Pleurotus tuber-regium (Fr.) Singer-Part 1: Effect of carbon-to-nitrogen ratio of the culture medium on the content and composition of the mycelial dietary fibre. Food Chemistry, 85, 101-105.

Yanga, J.-H., Linb, H.-C., \& Maub, J.-L. (2002). Antioxidant properties of several commercial mushrooms. Food Chemistry, 77, 229-235.

Zhang, A., Zhu, Q. Y., Luk, Y. S., Ho, K. Y., Fung, K. P., \& Chen, Z.-Y. (1997). Inhibitory effect of jasmine green tea epicatechin isomers on free radical-induced lysis of red blood cells. Life Sciences, 61, 383-394.

Zhong, J. J., \& Tang, Y. J. (2004). Submerged cultivation of medicinal mushrooms for production of valuable bioactive metabolites. Advances in Biochemical Engineering/Biotechnology, 87, 25-59. 